\title{
Relationship between ABO blood group system and falciparum malaria in paediatric age group
}

\author{
U. A. Munir ${ }^{1}$ \\ ${ }^{1}$ Dr. U.A. Munir, Associate Professor, Department of Pediatrics, Kerala Medical College, Mangode, Cherpulassery, \\ Palakkad District, Kerala, India
}

Address for Correspondence: Dr .U. A. Munir, Associate Professor, Department of Pediatrics, Kerala Medical College and Hospital, Mangode, Cherpulassery, Palakkad District, Kerala. Email: druamunir@rediffmail.com

\begin{abstract}
Background: The associations of $\mathrm{ABO}$ blood group with different diseases were being reported from time to time. Recent works from different parts of the world have shown that $\mathrm{O}$ blood group is less prone and $\mathrm{AB}$ and $\mathrm{B}$ group is more prone to developed severe falciparum malaria than other blood group. Objective: To study if there is any association existing between ABO blood group and severe falciparum malaria. Methods: This was tertiary case control study which included 309 cases of diagnosed falciparum malaria paediatric cases. 163 health controls were screened for ABO blood group. Clinical manifestations of the patients were recorded and classified as severe / complicated according to the WHO criteria. Statistical analysis was done to find out the $\mathrm{P}$ value and odds ratio. Result: Frequency of severity in ' $\mathrm{O}$ ' blood group patients was lower in comparison to the severity in A and B blood group. Blood group B was significantly associated with severity when compared with uncomplicated $(\mathrm{P}<0.05, \mathrm{OR}=0.56)$ and healthy controls $(\mathrm{P}<0.05, \mathrm{OR}=0.56)$ of the group $\mathrm{B}$. prevalence of $\mathrm{O}$ group in uncomplicated $(\mathrm{P}<0.001, \mathrm{OR}=13.32)$ and healthy controls $(\mathrm{P}<0.005, \mathrm{OR}=0.50)$ was significantly high compared to severe malaria of $\mathrm{O}$ group. Conclusion: This study shows the relative immunity of $\mathrm{O}$ group for the severity of falciparum malaria and relative high propensity of B blood group for the severity of falciparum malaria in the pediatric age group.
\end{abstract}

Keywords: Falciparum malaria, Blood groups, Pediatric age group

\section{Introduction}

The ABO blood group system is the best known as well as the most important system for blood group compatibility in clinical practice. There are a number of literature which associates $\mathrm{ABO}$ antigen with different diseases like sickle cell anaemia, gastric \& salivary cancer etc [1-3]. Recently there are some reports showing a survival advantage of $\mathrm{O}$ group individuals in severe falciparum malaria cases [4-6]. As plasmodium falciparum malaria has remained as a potential killer disease in India \& to the best of our knowledge, there are very few data existing in India especially in paediatric age group patients which can show the relationship between plasmodium falciparum malaria and $\mathrm{ABO}$ blood group, so this study with an objective to find out if there is any survival advantage of $\mathrm{O}$ group in severe falciparum $\&$ any blood group is having a

Manuscript received: $05^{\text {th }}$ October 2016

Reviewed: $12^{\text {th }}$ October 2016

Author Corrected; $20^{\text {th }}$ October 2016

Accepted for Publication: $29^{\text {th }}$ October 2016 higher propensity for severe falciparum malaria in this region.

\section{Methods}

In this hospital based case control study with a prior permission from the institutional ethical committee. 309 cases of diagnosed falciparum malaria of paediatric age group (slide positive) from the department of pediatrics, kerala Medical College and Hospital between January 2014- December 2015 were evaluated.

Under Leishman stain, peripheral smear examination was done for the type of malaria parasite and blood group assessment was done with the help of known antisera. Clinical manifestations of the patients were recorded and classified as severe / complicated according to the WHO criteria. Uncomplicated and healthy children served as our control. 
Exclusion criteria: Subjects associated with any bacterial infection (confirmed by specific tests) were excluded from the study. Blood groups of both cases and controls were determined. Statistical calculation was done to find the $\mathrm{P}$ value and Odds ratio (OR).

\section{Result}

Frequency of severity in ' $\mathrm{O}$ ' blood group patients was lower in comparison to the severity in A and B blood group. Blood group B was significantly associated with severity when compared with uncomplicated $(\mathrm{P}<0.05, \mathrm{OR}=0.56)$ and healthy controls $(\mathrm{P}<0.05, \mathrm{OR}=0.56)$ of the group $\mathrm{B}$. Prevalence of $\mathrm{O}$ group in uncomplicated $(\mathrm{P}<0.001, \mathrm{OR}=13.32)$ and healthy controls $(\mathrm{P}<0.005, \mathrm{OR}=0.50)$ was significantly high compared to severe malaria of $\mathrm{O}$ group (Table 1$)$.

Table 1: Prevalence of ABO blood group in diff. P. falciparum malaria categories and healthy controls

\begin{tabular}{|l|l|l|l|l|l|l|}
\hline $\begin{array}{l}\text { Blood } \\
\text { group }\end{array}$ & $\begin{array}{l}\text { Severe } \\
\text { malaria } \\
(\mathbf{n}=\mathbf{1 6 0})\end{array}$ & $\begin{array}{l}\text { Uncomplicated } \\
\text { malaria }(\mathbf{n = 1 4 9 )}\end{array}$ & $\begin{array}{l}\text { Healthy } \\
\text { control } \\
(\mathbf{n = 1 6 3 )}\end{array}$ & $\begin{array}{l}\text { Severe Vs } \\
\text { uncomplicated P } \\
\text { value, OR } *\end{array}$ & $\begin{array}{l}\text { Severe Vs } \\
\text { healthy control } \\
\text { P value, OR }\end{array}$ & $\begin{array}{l}\text { Uncomplicated } \\
\text { Vs healthy } \\
\text { control P value, } \\
\text { OR }\end{array}$ \\
\hline $\mathrm{O}$ & $54(34 \%)$ & $81(55 \%)$ & $82(51 \%)$ & & $<0.001,0.36$ & $<0.5,1.36$ \\
\hline $\mathrm{A}$ & $52(32 \%)$ & $21(14 \%)$ & $29(17 \%)$ & $<0.001,0.26$ & $<0.05,0.56$ & $>0.5,1.01$ \\
\hline $\mathrm{B}$ & $50(32 \%)$ & $42(28 \%)$ & $43(27 \%)$ & $<0.05,0.56$ & $>0.5,1.48$ & $<0.5,1.77$ \\
\hline $\mathrm{AB}$ & $04(2 \%)$ & $05(03 \%)$ & $09(05 \%)$ & $>0.5,0.83$ & $<0.005,0.50$ & $<0.5,1.17$ \\
\hline Non O & $106(66 \%)$ & $68(45 \%)$ & $81(49 \%)$ & $<0.001,13.32$ & $<$ \\
\hline
\end{tabular}

$* \mathrm{OR}=$ odds ratio

\section{Discussion}

In this study population, out of 160 numbers of severe falciparum malaria cases, $34 \%(n=54)$ cases were $O$ blood group in nature. This percentage is less in comparison to the number of $\mathrm{O}$ group patients of uncomplicated (55\%) and healthy control (51 \%) variety. But the percentage of A \& B group severe patients were more $(32 \%$ each $)$ than their uncomplicated (14\% \& $28 \%)$ and healthy counterparts (17\% \& $27 \%$ ), which showed the more propensity of falciparum severity in this blood groups. When the comparison of severe group with uncomplicated variety as well as severe group with healthy control taking $\mathrm{O}$ group as the reference, it was found that both $\mathrm{A}$ and $\mathrm{B}$ group had a statically significant association $(<0.001$ for $\mathrm{A}$ and $<0.05$ for $\mathrm{B}$ group) as well as high odds ratio (0.36 for A group and 0.56 for B). Values of odds ratio was higher for B blood group, which gave us an indication that the strength of association of severity with B group was more than even A group. This supports the findings of Pathirana et al [5] and Panda et al [8]. Comparison of severity between $\mathrm{O}$ group with all non $\mathrm{O}$ group \& found that there is a statistically significant association $(\mathrm{P}<0.001)$ exists where $\mathrm{O}$ group association with uncomplicated and healthy variety is more than the severe variety with a high odds ratio (13.32). This shows the protection of $\mathrm{O}$ group against the severity of falciparum malaria similar to the findings by other researchers [8-9]. So prognostically a better situation exists in $\mathrm{O}$ group paediatric patients, since severity is always associated with mortality in P. falciparum malaria. Similarly with an increased risk for development of severe malaria, blood group B pediatric patients remains in a prognostically bad condition. The influence of P. falciparum infection on the relative proportion of $\mathrm{ABO}$ antigen is mutually complex [10]. Malaria is known who have affected many erythrocyte genes including those concerned with globin synthesis, membrane proteins, and RBC enzymes. With a high degree of importance of $\mathrm{RBC}$ in malaria, there is a strong possibility of the influence of malaria on the antigen of RBC membrane. It has been found that the world wide prevalence of group $\mathrm{O}$ parallels with malaria region [7]. This again gives a possibility that a single point mutation of the RBC membrane protein gene may be favoring $\mathrm{O}$ group for the survival against P. falciparum. 


\section{Conclusion}

This study concluded that there is a relationship between blood group and severe falciparum. It showed the relative immunity of $\mathrm{O}$ group for the severity of falciparum malaria and relative high propensity of $\mathrm{B}$ blood group for the severity of falciparum malaria in the pediatric age group. However more studies are required from different parts of the globe, may be with higher sample size to investigate further and arrive at a definite conclusion.

\section{Funding: Nil, Conflict of interest: Nil \\ Permission from IRB: Yes}

\section{References}

1. Moulds JM and Moulds JJ. Blood group associations with parasites, bacteria and viruses. Transfus Med Rev. 2000 Oct;14(4):302-11.

2. Frattali A and spitalnik SL. Blood Group Antigens as Receptors for Pathogens. In Blancher A, Klein J, Socha WW (Eds.). Molecular Biology and Evolution of Blood group and MHC Antigens in Primates 1997; Heidelberg Springer PP. 268-304.

3. Aird I, Bentall HhH, Roberts JaA. A relationship between cancer of the stomach and the ABO blood groupsBr Med J. 1953 Apr 11;1(4814):799-801.

4. Lell B, May J, Schmidt - Ott RJ, et al. The role of red blood cell polymorphisms in resistance and susceptibility to malaria. Clin Infect Dis. 1999 Apr;28(4):794-9.

5. Pathirana SL. Alles HK, Bandara S, et al. ABO blood group types and protection against severe plasmodium falciparum malaria. Ann Trop Med Parasitol 2005; 99 : 119-124.

6. Fischer PR and Boone P. Short report : Severe malaria associated with blood group. Am J Trop Med Hyg. 1998 Jan;58(1):122-3.

7. Loscertales M-P, Brabin BJ. ABO phenotypes and malaria related outcomes in mothers and babies in the Gambia : a role for histo - blood groups in placental malaria ? Malaria J 2006; 5 : 1-6.

8. Panda AK, Panda Santosh K, Sahu AN et al. Association of $\mathrm{ABO}$ blood goup with severe falciparum malaria in adults : case control study and meta-analysis. Malar J. 2011 Oct 19;10:309. doi: 10.1186/1475-287510-309.

9. Cserti cm, Dzik WH. The ABO blood group system and plasmodium falciparum malaria. Blood. 2007 Oct 1;110(7):2250-8. Epub 2007 May 14.

10. World Health Organization Severe falciparum malaria. World Health Organization, Communicable Diseases Cluster. Trans R. Soc Trap Med. Hyg.2000; 94 : $1-90$.

\section{How to cite this article?}

U. A. Munir. Relationship between ABO blood group system and falciparum malaria in paediatric age group. Int. J PediatrRes.2016;3(11):866-868.doi:10.17511/ijpr.2016.i12.01. 